УДК 340.1

\author{
Наталія Олександрівна Клещенко, \\ аспірантка кафедри теорії держави і права \\ Начіонального педагогічного університету \\ імені М. П. Драгоманова
}

\title{
ЗНАЧЕННЯ ЮРИДИЧНОЇ ТЕХНІКИ ПРИ УНІФІКАЦІї ЗАКОНОДАВСТВА
}

Постановка проблеми. Проблема покращення якості законодавства залишається актуальною, незважаючи на значний масив наукових праць, які спрямовані для ії вирішення. На наш погляд, уніфікація $є$ найбільш оптимальним способом упорядкування чинного законодавства. Але хотілося б зупинитися на такому понятті, як юридична техніка, та довести ії значення при уніфікації.

Стійке функціонування механізму держави залежить від його інструментально-технологічної оснащеності. Наявність в арсеналі державних органів якісних правових засобів і технологій юридичної діяльності дає змогу успішно вирішувати завдання, які стоять перед Україною на сучасному етапі. Удосконалення правових технологій - необхідна умова підвищення ефективності роботи державних органів та одна 3 найважливіших проблем у сучасній юридичній науці $[5$, с. 1$]$. У колі науковців підтримується думка щодо того, що процес створення законодавчих норм права має реалізовуватися відповідно до строгих правил юридичної техніки, тобто систематизованих правил і прийомів, заснованих на практиці правотворчості, підготовки проектів нормативно-правових актів. Юридична техніка забезпечує вичерпне охоплення регульованих питань, зрозумілість, простоту та високу регулятивність правового матеріалу.

Аналіз останніх досліджень та публікацій. Питанням юридичної техніки присвячено праці таких вчених, як О. Богачова, О. Копиленко, I. Онищук, I. Шутак тощо.

Метою статті $\epsilon$ аргументувати значення юридичної техніки при уніфікації законодавства.

Основні результати дослідження. Неодноразово наголошувалося на значенні уніфікації в упорядкуванні законодавства. Проте, перед тим як розпочинати уніфікацію законодавства, слід привести техніко-юридичні правила до єдиної системи.

Дійсно, у сучасних намаганнях контролювати та оцінювати законність і справедливість існує ціла низка спірних питань. Для цього необхідно дотримуватися чіткого механізму дій, які законодавчо закріплені. Проте на шляху до цього існує чимало перешкод, однією з яких є законодавчо не врегульована юридична техніка. Остання з усіма на це підставами може вважатися саме тим інститутом, що надає можливість не тільки сформулювати зміст правового акта, а й забезпечити адекватне його усвідомлення, можливість коригувати ті або інші правовідносини у відповідності до їх реалій.

Однією з необхідних умов удосконалення законотворення є оволодіння системою вимог, що висуваються до процесу створення законів. Ці вимоги формулюються в галузі знань, відомій як юридична техніка. Наслідком їх ігнорування $\epsilon$ недосконалість створюваних законів, що негативно відображається на режимі правопорядку в країні. Недослідженими залишаються питання співвідношення технологій законотворення в сучасних правових системах, а це є особливо актуальним у контексті визначення оптимального співвідношення міжнародного та національного права, забезпечення належної їх взаємодії у спільному правовому полі. Адже порушення меж одного виду правотворчості іншим веде до юридичних колізій, зниження рівня правового регулювання [12, с. 3$]$.

У процесі еволюції права відбулося його виокремлення з нормативної системи первіснообщинного ладу. Саме тоді розпочався етап розвитку інституту юридичної техніки. Поділ суспільства на соціально неоднорідні групи спричинив перехід від соціального регулювання, що регулювало суспільні відносини за допомогою соціальних норм, до безпосередньо нормативного регулювання, а відтак зумовив появу юридичної техніки, що виступала як формалізований регулятор для надання праву системних і структурних ознак [13, с. 17].

Окремо хотілося б наголосити на тому, що в період розширення меж європейської міжнародної правотворчої діяльності особливої актуальності набуває вивчення юридичної техніки та техноло- 
гії. Таке розширення закріплюється в установчих документах міждержавних організацій і потребує від держави цілеспрямованої діяльності щодо забезпечення підготовки до впровадження результатів міжнародного правотворення в національне правове поле. Скарбниця юридично-технічних знань для кожного представника юридичної професії $є$ необхідною для виконання найбільш спільних завдань і персоніфікованою стосовно завдань та функцій, що входять до посадової компетенції [10, с. 37]. Недотримання правил юридичної техніки в тексті правових актів породжує безліч юридичних помилок, як неповне закріплення обставин, що мають істотне значення для змісту і застосування конкретної правової норми, або навіть і закріплення норм, що суперечать Конституції України. Усе це помітно знижує якість законодавчих актів, викликає труднощі в їх тлумаченні і перешкоджає реалізації норм права в конкретних суспільних відносинах.

На жаль, питання щодо врегулювання юридичної техніки в нашій країні залишається відкритим. Хоча проект Закону України «Про нормативно-правові акти» від 21.01.2008 року та пропозиції Президента України до Закону України «Про нормативно-правові акти» від 22 грудня 2009 року передбачали врегулювання вимог до юридичної техніки в нормативно-правових актах.

Для порівняльного прикладу в Японії ще у далекому1898 році було прийняте «Загальне положення про закони». Подібні правові акти були прийняті і в інших державах. Зокрема в Болгарії «Закон про нормативні акти» існує з 29.03.1973 року, а в Угорщині діє «Закон про правотворчість» з 1987 року, відповідні документи є в Австрії, ФРН і США. У1976 році Декретом Державної Ради Румунії затверджено «Загальну методологію законодавчої техніки», де перелічено основні категорії нормативних актів [3, с. 26].

Юридична техніка - це особлива теоретико-прикладна правова наука, предметом вивчення якої $\epsilon$ закономірності раціональної правової діяльності зі створення, тлумачення та реалізації норм права. У системі юриспруденції юридична техніка покликана вирішувати завдання систематизації знань про прийоми та методи юридичної діяльності, що формуються загальною теорією права, галузевими та прикладними юридичними науками $[10$, с. 38]. Ціль юридичної техніки - наситити систему правовим матеріалом, удосконалити мову правового акта, зробити його більш зрозумілим і точним. Багато в чому саме розвиненість юридичної техніки символізує певний рівень правової культури конкретного суспільства [2, с. 105].

Процес уніфікації є тим універсальним способом, який здатен навести лад як і в самій системі законодавства так і в правилах його творення. Мається на увазі уніфікація юридичної техніки.

Уніфікація вимог законодавчої техніки, які використовуються суб'єктами законотворення при підготовці законодавчих актів, єдність їх застосування в межах не лише окремого законопроекту, а й в усій практиці законотворення вбачається одним з пріоритетних напрямів забезпечення вдосконалення законодавчих текстів, створення єдиного правового простору [1, с. 156]. I взагалі, питання що стосуються функціонування системи нормативно-правових актів та юридичної техніки, потребують повноцінного правового врегулювання. Вважаємо, що без спеціальної проблематизації юридичної техніки недоцільно говорити про вирішення питань удосконалення правотворчої діяльності, підвищення юридичної якості законодавчих актів та забезпечення ефективності правового регулювання суспільних відносин.

Юридична техніка підпорядкована певним вимогам. Необхідність дотримання цих вимог викликана тим, що правовий акт - твір особливого роду, відмінний від наукової праці, чи художнього твору, наприклад. Призначення нормативно-правового акта, на відміну від інших творів, - якісно регулювати суспільні відносини, визначати юридичні гарантії, запроваджувати заходи щодо забезпечення виконання правових приписів тощо. А відтак, недотримання правил юридичної техніки веде до прогалин та неузгодженостей різного роду.

Техніка юридичного письма незамінна в якості ідеальної і матеріальної основи професійної компетентності парламентаріїв, державних службовців, юристів-професіоналів. Крім того, професійні навички письма мають важливе значення для успіху в багатьох інших сферах $[5$, с. 5]. Сприйняття змісту нормативного акта полегшує універсалізація форми висловлення думки, яка сконцентровує увагу на кожному його положенні, і таким чином спрощує процес складання окремих документів. Виклад тексту в НПА містить певним чином оформлені аргументи для обгрунтування положень і тверджень. Це не лише словесно оформлені міркування, аналітичні положення, але й різні посилання, таблиці, виноски (найбільш часто зустрічаються у підзаконних актах) тощо. Стереотипна організація тексту виявляється у стандартизації правових актів [4]. 
Особливе значення 3-поміж інструментів юридичної техніки посідає техніка правового моніторингу. Правовий моніторинг - комплексна, систематична діяльність, спрямована на спостереження, аналіз, оцінювання чинного законодавства та практики його застосування, з метою підвищення ефективності законодавства і його подальшого прогнозування. Парламент потребує якісного механізму прогнозування можливих наслідків законодавства, відстежування його ефекту і використання результатів таких операцій у своїй законотворчій діяльності [13, с. 38].

На нинішньому етапі реформування законодавчого масиву Україна потребує уніфікації вимог законодавчої техніки, а саме детальної розробки та нормативного закріплення відповідних стандартів, які б широко застосовувалися та мали обов'язковий статус.

Як правило, погано піддаються уніфікації правові акти, пов'язані з регулюванням специфічно відокремлених суспільних відносин, що відображають індивідуальні можливості різних суб'єктів права (трудові відносини, відносини в галузі авторського права тощо). Труднощі уніфікації можуть мати й суто юридичний характер. Різнорідність правової матерії настільки велика, що вона не завжди піддається об'єднанню, хоча практична потреба в цьому очевидна. Може бути недосконалою і техніка уніфікації певної галузі законодавства, пов'язана з відсутністю досконалих правил здійснення подібних операцій $[8$, с. 230].

3 метою дослідження юридичної техніки, розробки концепцій техніко-юридичного забезпечення законотворчої діяльності як на загальнодержавному, так і на регіональному рівнях у 2011 р. вченими-однодумцями було засновано першу в Україні Лабораторію академічних досліджень правового регулювання та юридичної техніки в м. Івано-Франківськ. Члени Лабораторії є ініціаторами, співорганізаторами та учасниками всеукраїнських науково-практичних конференцій, де предметом всебічного висвітлення та дискусії виступають питання юридичної техніки [11, с. 34].

Проблема юридичної техніки на сучасному етапі реформування українського законодавства $\epsilon$ актуальним, проте недостатньо досліджуваним.

Наявність належного рівня правового забезпечення формування норм національного права відіграє принципове значення як для теорії, так і для юридичної практичної діяльності, адже забезпечує упорядкування здійснення національної правотворчості, визначає іiї основоположні процесуальні аспекти, забезпечує формування якісних норм національного права. В свою чергу, недостатнє правове регулювання формування норм права призводить не лише до правотворчих помилок і як наслідок існування неякісного законодавства, але й до можливості ускладнення взаємин між суб'єктами правотворчості, що негативно впливатиме на їх діяльність [9, с. 180]. Так, а правотворча діяльність в Україні $є$ широкомасштабною та складною діяльністю уповноважених державних органів та посадових осіб з питань підготовки і прийняття нормативно-правових актів, призначення яких полягає в ефективному регулюванні суспільних відносин. Результат такої діяльності напряму залежить від підготовки таких нормативно-правових актів, які повинні бути досконалими за формою і змістом, тобто задовольнити високі вимоги стосовно їх якості [7, c.14]. На наш погляд, уніфікація юридичної техніки - перший крок на шляху до упорядкування всього законодавчого масиву.

Висновки. Досконала нормативно-правова база - мета, до якої прагне кожна держава. Відповідно до цього законодавчі акти повинні володіти найвищим рівнем відповідності вимогам не тільки державним стандартам, але й юридичної техніки загалом. Уніфікація юридичної техніки $є$ першим етапом на шляху до створення якісної національної нормативної бази.

\section{Список використаних джерел}

1. Законопроектування: сучасні реалії та тенденції розвитку: моногр. / О. Л. Копиленко, О. В. Зайчук, О.В.Богачова та ін.; за ред. О. В. Зайчука, О. В. Богачової. - К. : Інститут законодавства Верховної Ради України; Кам’янець-Подільский : ТОВ «Друкарня Рута», 2014. - 232 с.

2. Ибраева A. С. Теория государства и права : учеб.пособие. 2-е изд. с доп. и изм. - Алматы : Жеті; жаргы, 2006. $-424 \mathrm{c}$.

3. Онищук I. I. Проблеми вдосконалення нормативно-правового регулювання вимог до юридичної техніки // Юридична Україна: [наук. журн.]. - К. : Юрінком Інтер, 2011. - № 6 (102). - С. 22-27.

4. Онищук I. I. Лінгвістична структура тексту нормативно-правового акта як засіб техніки юридичного письма / I. І. Онищук // Науковий вісник Академії муніципального управління. Серія: Право. - 2011. - Вип. 2. C. 213-221 [Електронний ресурс]. - Режим доступу : http://nbuv.gov.ua/UJRN/Nvamu_pr_2011_2_25 
5. Онищук I. I. Техніка юридичного письма в нормативно-правових актах : автореф. ... канд. юрид. наук. / I. І. Онищук. - Л., 2012. - 21 с.

6. Онищук I. I. Техніка юридичного письма в нормативно-правових актах : моногр. / I. I. Онищук. - ІваноФранківськ: Лабораторія академічних досліджень правового регулювання та юридичної техніки, 2014. - 228 с.

7. Панов М. I. Точність правових норм як необхідна умова якості право творення / М. І. Панов // Юридична техніка: доктринальні основи та проблеми викладання: тези доповідей учасників науково-практичної конференції (м. Харків, 30 вересня - 1 жовтня 2015 р.) / за ред. проф. В. В. Комарова та І. Д. Шутака. - Харків : Нац. Юрид.ун-т ім. Ярослава Мудрого, 2015. - С. 12-14.

8. Порівняльне правознавство (теоретико-правове дослідження) / О. Л. Копиленко [та ін.] ; наук. ред. Н. М. Оніщенко ; відп. ред. О. В. Зайчук; Інститут законодавства Верховної Ради України, Інститут держави і права ім. В. М. Корецького НАН України. - К. : Фенікс, 2007. - 430 с.

9. Стрипко М. Я. До питання термінологічних колізій у нормотворчій діяльності / М. Я. Стрипко // Бюлетень Міністерства юстиції України. - 2007. - № 5. - С. 178-183.

10. Шутак I. Д. Юридична техніка і технологія:т еорія та практика застосування / І. Д. Шутак // Вісник Львівського університету. Серія юридична. 2016. - Вип. 63. - С. 37-45.

11. Шутак I. Д. Дослідження актуальних та пріоритетних напрямків у галузі юридичної техніки / I. Д. Шутак // Journal «ScienceRise: Juridical Science» №1(1)2017. - С. 32-36.

12. Шутак I. Д. Законотворення в сучасних європейських правових системах: техніко-технологічний аспект // Проблеми законодавчого регулювання порядку розробки та прийняття нормативно-правових актів : тези доп. та повідомл. сучасн. ІІІ Міжнар. наук.-практ. конф. (м. Київ, 2-3 листоп. 2017 р.) / за заг. ред. І. Д. Шутака. Харків : Право, 2017. - С. 3-8.

13. Шутак I. Д., Онищук I. І. Юридична техніка : навч. посіб. для вищих навчальних закладів / I. Д. Шутак, I. I Онищук. - Івано- Франківськ, 2013. - 496 с.

\section{References}

1. Zakonoproektuvannia: suchasni realii ta tendentsii rozvytku : monohrafiia / O. L. Kopylenko, O. V. Zaichuk, O. V. Bohachova ta in.; za red. O.V. Zaichuka, O. V. Bohachovoi. - K.: Instytut zakonodavstva Verkhovnoi Rady Ukrainy; Kamianets-Podilskyi: TOV «Drukarnia Ruta», 2014. - 232 s.

2. Ibraeva A. S. Teoriya gosudarstva i prava: Ucheb.posobie. 2-e izd. s dop.i izm. - Almaty : Zheti ;zhargy, 2006. - 424 s.

3. Onyshchuk I. I. Problemy vdoskonalennia normatyvno-pravovoho rehuliuvannia vymoh do yurydychnoi tekhniky // Yurydychna Ukraina: [nauk. zhurn.]. K. : Yurinkom Inter, 2011. - № 6 (102). - S. 22-27.

4. Onyshchuk I. I. Linhvistychna struktura tekstu normatyvno-pravovoho akta yak zasib tekhniky yurydychnoho pysma / I. I. Onyshchuk // Naukovyi visnyk Akademii munitsypalnoho upravlinnia. Seriia: Pravo. - 2011. - Vyp. 2. S. 213-221[Elektronnyi resurs]. - Rezhym dostupu : http://nbuv.gov.ua/UJRN/Nvamu_pr_2011_2_25

5. Onyshchuk I. I. Tekhnika yurydychnoho pysma v normatyvno-pravovykh aktakh: avtoref. ... kand. yuryd. nauk. / I. I. Onyshchuk. - L., 2012. - 21 s.

6. Onyshchuk I. I. Tekhnika yurydychnoho pysma v normatyvno-pravovykh aktakh: monohrafiia / I. I. Onyshchuk. Ivano-Frankivsk : Laboratoriia akademichnykh doslidzhen pravovoho rehuliuvannia ta yurydychnoi tekhniky, 2014. $-228 \mathrm{~s}$.

7. Panov M. I. Tochnist pravovykh norm yak neobkhidna umova yakosti pravo tvorennia / M.I. Panov // Yurydychna tekhnika: doktrynalni osnovy ta problemy vykladannia: tezy dopovidei uchasnykiv naukovo-praktychnoi konferentsii (m. Kharkiv, 30 veresnia - 1 zhovtnia 2015 r) / za red.. prof.. V.V. Komarova ta I.D. Shutaka. - Kharkiv: Nats. Yuryd. un-t im. Yaroslava Mudroho, 2015. - S. 12-14.

8. Porivnialne pravoznavstvo (teoretyko-pravove doslidzhennia) / O. L. Kopylenko [ta in.]; nauk. red. N. M. Onishchenko; vidp. red. O. V. Zaichuk; Instytut zakonodavstva Verkhovnoi Rady Ukrainy, Instytut derzhavy i prava im. V. M. Koretskoho NAN Ukrainy. - K. : Feniks, 2007. - 430 s.

9. Strypko M. Ia. Do pytannia terminolohichnykh kolizii u normotvorchii diialnosti / M. Ia. Strypko // Biuleten Ministerstva yustytsii Ukrainy. - 2007. - № 5. - S. 178-183.

10. Shutak I. D. Yurydychna tekhnika i tekhnolohiia:teoriia ta praktyka zastosuvannia / I.D.Shutak // Visnyk Lvivskoho universytetu. Seriia yurydychna. 2016. - Vypusk 63. - S. 37-45.

11. Shutak I. D. Doslidzhennia aktualnykh ta priorytetnykh napriamkiv u haluzi yurydychnoi tekhniky / I. D. Shutak // Journal «ScienceRise: Juridical Science» №1(1)2017 - S. 32-36.

12. Shutak I. D. Zakonotvorennia v suchasnykh yevropeiskykh pravovykh systemakh: tekhniko-tekhnolohichnyi aspekt // Problemy zakonodavchoho rehuliuvannia poriadku rozrobky ta pryiniattia normatyvno-pravovykh aktiv: tezy dop. ta povidoml. suchasn. III Mizhnar. nauk.-prakt. konf. (m. Kyiv, 2-3 lystop. 2017 r.) / za zah. red. I. D. Shutaka. Kharkiv : Pravo, 2017. - S. 3-8

13. Shutak I. D., Onyshchuk I.I. Yurydychna tekhnika: navchalnyi posibnyk dlia vyshchykh navchalnykh zakladiv / I. D. Shutak, I.I.Onyshchuk. - Ivano- Frankivsk, 2013. - 496 c. 


\section{Клещенко Н. О. Значення юридичної техніки при уніфікації законодавства}

У статті досліджується вплив юридичної техніки на процес уніфікації законодавства. Робиться акцент на юридичній техніці як на першому, основоположному кроці до упорядкування всієї системи законодавства. Наголошується, що юридична техніка є відносно новим правовим явищем, і відтак, потребує глибокого дослідження. Звертається увага, що недотримання вимог юридичної техніки веде до значних прогалин в текстах правових актів, що створюються. Юридична техніка виступає свого роду уніфікованим інструментарієм.

Ключові слова: уніфікація законодавства, юридична техніка, правовий моніторинг, правове регулювання, система законодавства.

\section{Kleshchenko N. O. Significance of legal technique at unification of the legislation}

The article examines the impact of legal technology on the process of unification of legislation. The emphasis is on legal technology as a first, fundamental step to streamline the whole system of legislation. The scientific community supports the idea that the process of creating legal norms of law should be implemented in accordance with strict rules of legal technology, that is, systematic rules and techniques based on the practice of law-making, drafting regulations.

It is noted that legal technology is a relatively new legal phenomenon, and therefore requires a profound study. However, with all of this, it can be considered to be the very institution that provides the opportunity not only to formulate the content of the legal act, but also to ensure its high-level awareness, the ability to adjust one or another legal relationship in accordance with their realities.

Attention is drawn to the fact that non-compliance with the requirements of legal technology leads to significant gaps in the texts of legal acts that are being created. The result of its ignoring is the imperfection of the laws that are being created, which is negatively reflected in the rule of law in the country. Failure to comply with the rules of legal technique in the text of normative legal acts generates many legal errors such as, for example, incomplete consolidation of circumstances that are essential for the content and application of a specific legal norm, etc. All this significantly reduces the quality of legislative acts, raises difficulties in their interpretation and prevents the implementation of the rules of law in specific social relations. The aim of legal technique is to fill the system with legal material, to improve the language of the normative legal act, to make it more precise and understandable for society.

The process of unification, in our opinion, is the universal way that is capable of establishing order both in the very system of legislation and in the rules of its writing. It means unification of legal technique. That is, legal technology is a kind of unified toolkit.

Key words: unification of legislation, legal technique, legal monitoring, legal regulation, system of legislation.

DOI: 10.33.66.3/2524-017X-2019-10-138-142

УДК 340

Ольга Геннадї̈вна Кобан,

асистент кафедри теорії права та держави юридичного факультету Київського начіонального університету імені Тараса Шевченка, кандидат юридичних наук

\section{МОНІТОРИНГ СОЦІАЛІЗАЦІї ДІЯЛЬНОСТІ ОРГАНІВ ВИКОНАВЧОЇ ВЛАДИ}

Постановка проблеми. Постійне реформування в соціальній економічній і політичній сферах демократизація всіх сфер суспільного життя та ускладнення соціальних завдань, які суспільство наразі висуває перед державою, поставили всі державу перед необхідністю небувалого досі зближення із суспільством. Взяття за основу парадигми «людина - держава» стало можливим завдяки створенню об' єктивних передумов до широкої самореалізації особи в політиці і праві, ствердженню правових основ у взаємодії державної влади із громадянським суспільством. Перехід від вузького позитивістського розуміння права як права влади до широкого розуміння права як міри свободи визначив гуманістичний ціннісний зміст права, в якому переважають загальнолюдські цінності; право $є$ засобом, за допомогою якого вони реалізуються. Право не обмежується роллю нормативно- 